\title{
Land Grab, Property Rights and Gender Equality in Pluralistic Legal Orders: A Nigerian Perspective
}

\author{
Chilenye Nwapi \\ Research Associate, Canadian Institute of Resources Law, \\ Murray Fraser Hall 3351A, 2500 University Dr NW, \\ Calgary, Alberta $\mathrm{T}_{2} \mathrm{~N}_{1} \mathrm{~N}_{4}$, CANADA \\ cnwapi@ucalgary.ca
}

\begin{abstract}
This article considers the impact of land grab on the promotion of gender inequality within the Nigerian pluralistic legal order. It examines the interface between customary law and statute law in the determination of land ownership and access in Nigeria. It makes two key arguments. (1) While legal pluralism presents opportunities for curtailing the excesses of customary law, it has often resulted in the dominant legal system - statute law - fostering gender inequality in a manner that is beyond the capacity of the so-called barbaric customary laws. (2) The capacity of law to effectively address the problem of gender inequality within the context of land grab is very limited, because the nature of most land grab-related activities that promote gender inequality are appropriately legal and it is their unintended consequences that undermine women's rights. The article argues for an effective use of the political process to complement legal interventions.
\end{abstract}

\section{Keywords}

land grab - customary law - statute law - legal pluralism - property rights - gender inequality

The average Nigerian is subject to at least two distinct, often conflicting, legal orders: customary law (or religious law) and statute law. While customary 
law typically regulates family relations, statute law regulates other aspects of existence. Legal pluralism - the existence of two or more legal orders within the same spatial and temporal space - presents both opportunities and challenges for the protection of property rights and gender equality in the context of land acquisition. This article assesses the impact of the phenomenon of land grab - loosely defined as the large-scale acquisition of land for agricultural purposes by large agri-businesses, be they foreign or nationals - on property rights and gender equality in Nigeria. It examines the interface between customary law and statute law in the determination of land ownership and access in Nigeria. The discussions will enable us to understand the nature of the tension between these two normative legal orders in Nigeria (i.e., customary law and statute law) and how this tension plays out in the context of land grab to further entrench gender inequality. The article will examine attempts by Nigerian courts to reconcile this tension with a view to promoting gender equality.

The article makes two key arguments. The first is that while the existence of legal pluralism presents opportunities for curtailing the excesses of customary law, those opportunities have been often misused, often resulting in legal pluralism fostering gender inequality in a manner and to such an extent that the so-called barbaric customary laws could not have achieved. Thus, while many customary laws in Nigeria promote gender inequality, under the guise of promoting economic development statute law often erodes many of the few women's property rights guaranteed under customary laws. The second argument is that the capacity of law to effectively address the problem of gender inequality within the context of land grab is very limited. It is limited because the nature of most of the land grab-related activities that undermine women's rights are perfectly legal and are approved even in so-called civilized societies that enjoy a great human rights reputation and it is only their unintended consequences that undermine women's rights. Political interventions are needed to complement legal interventions.

The discussion proceeds as follows. Section II describes the phenomenon of land grab in Nigeria. Section III analyzes the meaning, advent and evolution of legal pluralism in Nigeria and illustrates the nature of the interaction among the prevailing legal orders. Section IV analyzes key relevant issues in land ownership and control in Nigeria. Section $\mathrm{v}$ discusses the implications of legal pluralism for the protection of gender equality over property rights in Nigeria while Section VI addresses the legal and jurisprudential bases for challenging gender discrimination in the context of land grab in Nigeria. Section vil summarizes the arguments of the article. 
Not all land acquisitions are land grabs. According to the Tirana Declaration of the International Land Coalition, land grabs are:

[land] acquisitions or concessions that are one or more of the following: (i) in violation of human rights, particularly the equal rights of women; (ii) not based on free, prior and informed consent of the affected landusers; (iii) not based on a thorough assessment, or are in disregard of social, economic and environmental impacts, including the way they are gendered; (iv) not based on transparent contracts that specify clear and binding commitments about activities, employment and benefits sharing, and; (v) not based on effective democratic planning, independent oversight and meaningful participation. ${ }^{1}$

Although land grab is not a recent phenomenon, both the number of land deals and the size of the lands being grabbed have risen dramatically over the past five years. ${ }^{2}$ The rise is driven by several factors, including (1) rising demand for food in emerging economies such as China and India, (2) the need for developing countries to boost their own domestic food production, (3) water and land scarcity in several parts of the world, (4) the drive for foreign direct investment (FDI), and (5) mineral resource exploration. ${ }^{3}$ Most of the deals occur in Africa and to a lesser extent in Asia and Latin America. In 2009 alone, over two-thirds of the global total area of grabbed land were in Sub-Saharan Africa. ${ }^{4}$ While the major countries of origin of land grabbers are Asian (China, India, Saudi Arabia, United Arab Emirates, Qatar, Kuwait and Bahrain), North African (Libya and Egypt) and the United Kingdom and the United States, ${ }^{5}$ the major

1 International Land Coalition, 'Tirana Declaration: Securing Land Access for the Poor in Times of Intensified Natural Resources Competition' (26 May 2011) para $4<$ www.landcoalition .org/sites/default/files/documents/resources/tiranadeclaration.pdf> accessed 1 March 2017.

2 Jo Nnabuko and CU Uche, 'Land Grab and the Viability of Foreign Investments in SubSaharan Africa: The Nigerian Experience' in Emmanuel Yneshu Vubo (ed), Environment, Agriculture and Cross-border Migrations (CODESRIA 2015) 87.

3 Ibid. See, also, Ayodele F Odusola, 'Land Grab in Africa: A Review of Emerging Issues and Implications for Policy Options', Working Paper \#124, International Policy Centre for Inclusive Growth, April 2014, 1 <http://citeseerx.ist.psu.edu/viewdoc/download?doi=10.1.1.639.5098\& rep=rep1\&type $=$ pdf $>$ accessed 1 March 2017.

4 Ibid.

5 Ibid. 
scenes of the acquisitions are in Africa (particularly Sudan, Mozambique, Mali and Ethiopia). ${ }^{6}$

Land grab is also occurring in Nigeria. The urge to boost domestic food production has driven the Nigerian government to allocate large swaths of land to foreign and domestic investors for large-scale agricultural projects. The allocations began most noticeably in 2005 when a group of white farmers kicked out of Zimbabwe by President Robert Mugabe came to Nigeria in search of alternative venues for agricultural investments in Africa. Then Nigeria's President Olusegun Obasanjo assured the farmers that "there's no need to worry about land"7 and got the Kwara State Governor to allocate almost 200,00o hectares of land to the farmers ${ }^{8}$ and promised to sell the "Kwara programme to a few more states." 9

As a member of the New Alliance for Food Security and Nutrition launched by the G8 in L'Aquila, Italy in 2012, Nigeria committed to specific policy and investment interventions that would accelerate growth in the agricultural sector in Africa. The commitments are organized in a cooperation framework ${ }^{10}$ negotiated by the Alliance members. The framework for Nigeria covers four areas: (a) agricultural inputs (seed and fertilizer), (b) agricultural finance, (c) food security and nutrition and (d) enabling environment for private sector investment in agriculture. ${ }^{11}$

The Alliance is integrated into Nigeria's Agricultural Transformation Agenda (ATA) - the Nigerian government's implementation plan for the Comprehensive African Agriculture Development Program launched in 2003

$6 \quad$ Nnabuko and Uche (n 2).

7 'Nigeria welcomes white farmers', Zim Crisis Reports, cited in Akachi Odoemene, 'Competing Rhetoric in the Context of Foreign Land Acquisitions: The Case of "New Nigeria"' in Sandra Jтм Evers, Caroline Seagle and Froukje Krijtenburg, eds, Africa for Sale?: Position the State, Land and Society in Foreign Large-Scale Land Acquisitions in Africa (Koninklijke Brill NV, Leiden 2013) 266.

8 Ibid.

9 'Nigerian leader welcomes white Zim farmers' Male \& Guardian (30 August 2005) <http:// mg.co.za/article/2005-08-30-nigerian-leader-welcomes-white-zim-farmers > accessed 10 October 2016.

10 Cooperation Framework to Support the New Alliance for Food Security and Nutrition in Nigeria <https://new-alliance.org/sites/default/files/resources/new-alliance-progress -report-coop-framework-nigeria_compressed.pdf> accessed 10 October 2016.

11 Ibid 4. 
by the New Partnership for Africa's Development (NEPAD). ${ }^{12}$ The ATA is part of Nigeria's development policy plan launched in 2009 and tagged Vision 2020, which contains a "Seven Point Agenda" listing land reform, agriculture and food security as the focal policy areas. ${ }^{13}$ The aims of the ATA include the promotion of agribusiness and private sector investment in agriculture and the enhancement of farmers' access to market and finance. ${ }^{14}$

One of the implementation measures for the Alliance and the ATA is the allocation of large swaths of land to foreign and domestic investors for large scale agricultural projects. One of the most notorious of such projects is a 38,00o hectare of land in Taraba State, northeastern Nigeria, allocated to Dominion Farms Limited - a Kenya-registered company with its headquarters in Oklahoma, United States - for large-scale rice production. ${ }^{15}$ The land was part of a large strip of land allocated in 1978 to the Upper Benue River Basin Development Authority, an agency established to support local farmers in Benue State to construct irrigation projects, farm access roads, stores and warehouses, and to protect against floods. ${ }^{16}$ However, according to the Centre for Environmental Education and Development (CEED), the memorandum of understanding (MOU) between the Nigerian government and Dominion

12 NEPAD, 'Comprehensive African Agriculture Development Program' (July 2003) <www .fao.org/nr/water/aquastat/sirte2008/NEPAD-CAADP\%202003.pdf> accessed 1 March 2017.

13 See 'Overview of President Yar'adua's Seven Point Agenda: Issues and Policy Challenges', Nigerian High Commission, UK <www.nigeriahc.org.uk/pdf/seven_point_agenda.pdf> accessed 12 October 2016; Robert Oghenedoro Dode, 'Yar'adua 7-Point Agenda, the MDGs and Sustainable Development in Nigeria' (2010) 10(4) Global Journal of Human Social Science $2-8$.

14 African Development Bank, 'Agricultural Transformation Agenda Support Program Phase 1 (ATASP-1): Nigeria - Strategic Environmental and Social Assessment', July 2013, 3 <www.afdb.org/fileadmin/uploads/afdb/Documents/Environmental-and -Social-Assessments/Nigeria\%20-\%20Agricultural\%20Transformation\%2oAgenda\%20 Support\%2oProgram \%20\%E2\%80\% 93\%2oPhase\%201\%20(ATASP-1)\%20-\%20 Executive\%2oSESA\%20Summary.pdf > accessed 12 October 2016.

15 Centre for Environmental Education and Development (CEED) et al, "The Dominion Farms Land Grab in Nigeria', January 2015, $2<$ www.globaljustice.org.uk/sites/default/files/ files/resources/dominion_farms_land_grab_in_nigeria_-_web.pdf> accessed 12 October 2016.

16 Oliver Tickell, 'Nigerian farmers face destitution from 300 sq.km land grab backed by uk aid' The Ecologist (28 January 2015) < www.theecologist.org/News/news_analysis/2731886/ nigerian_farmers_face_destitution_from_30o_sqkm_land_grab_backed_by_uk_aid.html> accessed 12 October 2016. 
Farms was signed without consultation with the local communities who depend on the land for their livelihood and the details of its contents remain undisclosed to the public. ${ }^{17}$ Moreover, neither was the MOU preceded or accompanied by a social and/or environmental impact assessment of the project nor was there any resettlement plan for the displaced local farmers. ${ }^{18}$ This exemplifies how land grab dispossesses local people of their lands and undercuts their livelihood.

Another notable case was Wilmar International Ltd's large-scale acquisition of land for palm oil plantations in Cross River State, southern Nigeria. The Singaporean oil palm giant, which entered into a joint venture with British commodity giant Pz Cussons to form PZ Wilmar Ltd, committed to develop 50,000 hectares of oil palm plantations and to establish palm oil processing mills in Cross River State with a total investment of $\$ 550$ million. ${ }^{19}$ The acquisition of the land was part of the Nigerian government's efforts to attract "high capacity" foreign investors to resuscitate its moribund oil palm plantation industry. ${ }^{20}$ The land was used by the local communities for plantains, cocoyam, cassava, vegetables and timber cultivation..$^{21}$ The local communities surrounding the land lament that the land was allocated to Wilmar without their knowledge, let alone consent. ${ }^{22}$

Various observations have been provided on how Wilmar's acquisition will affect local communities in Cross River State. Shaik and Ojo observe that the acquisition has resulted in deforestation of the area. ${ }^{23}$ It has been estimated that about 10,000 people would potentially be displaced from their lands as a result of Wilmar's operations and that the livelihood of up to 20,000 people may be affected negatively. ${ }^{24}$ It has also been observed that Wilmar's

17 CEED (n 15) 2.

18 Ibid 6.

19 Friends of the Earth (FoE) Us/Environmental Rights Action (ERA) Nigeria, 'Exploitation and Empty Promises: Wilmar's Nigerian Land Grab', Friends of the Earth, July 2015 12 <www.foeeurope.org/sites/default/files/corporate_accountability/2015/foe_ exploitationandempty_lowres_rev.pdf> accessed 12 October 2016.

Anne van Schaik and Godwin Ojo, 'Deforestation, exploitation, hypocrisy: no end to Wilmar's palm oil land grabs', Farmland Grab, 29 May 2015 <http://farmlandgrab.org/ post/view/24979-deforestation-exploitation-hypocrisy-no-end-to-wilmar-s-palm-oil -land-grabs> accessed 12 October 2016.

21 Ibid.

22 FoE(Us) \& ERA (n 19) 2.

23 Schaik and Godwin Ojo (n 20).

24 Rainforest Resources Development Centre and Environmental Rights Action, 'Large-scale Palm Oil Production, Environment and Livelihood of Local Communities in Nigeria: The 
operations have occasioned a "widespread displacement of smallholder production systems", with "few mechanisms through which affected households can claim redress." ${ }^{25}$ Although Wilmar has provided jobs to some community members, these jobs are mostly day labourer positions that pay the beneficiaries less than they earned from their small scale farming. ${ }^{26}$

The challenge to land grab in Nigeria particularly by transnational agroinvestors is its threat to food sovereignty and the violation of internationally recognized rights of local people. From the definition of land grab proffered in the Tirana Declaration, it is clear that the problem with land grab is not quite the fact that traditional landowners are dispossessed of their lands but the manner of acquisition/dispossession, which is what makes it a grab. Where, therefore, the acquisition is based on free, prior and informed consent of the local communities who depend on the land for their livelihood, where the acquisition is sensitive to the equality rights of women and is undertaken only after a socio-environmental impact assessment that respects the principles of transparency and public participation has been carried out, the acquisition would be reasonable and legitimate. It is a question of ensuring that these land deals take into account local interests and do not result in unreasonable displacement of local farmers. It is therefore a question of "striking a delicate balance between competing land use systems and economic and political interests."27 The principal instrument for striking this balance is law, and it is from this perspective that the relevance of examining the impact of legal pluralism on Nigeria's land tenure system becomes readily apparent. However, it will also be seen, as the discussions in this article progress, that while law remains an important and indispensable tool to strike this balance, it has its own inherent limitations. Political interventions are required to fill the gap.

Case of Wilmar Plantations in Cross-River State', Report published in Nigeria, November 2014, cited in FoE(US) \& ERA (n 19) 19.

25 GC Schoneveld, 'The Politics of the Forest Frontier: Negotiating between Conservation, Development, and Indigenous Rights in Cross River State, Nigeria' (2014) 18 Land Use Policy 156.

26 Schaik \& Godwin Ojo (n 20).

27 Schoneveld (n 25) 148. 


\section{Meaning, Advent and Operation of Legal Pluralism in Nigeria}

Legal pluralism refers to the operation of more than one legal order, "de jure or de facto ... within the same geographical and temporal space."28 Practically, it is a situation whereby customary or religious laws operate side by side with state laws, each constituting a recognized source of binding law. State laws, in the sense used here, refer to laws (known as statutes or codes and all subsidiary legislation made pursuant to them) enacted by the law-making organs of a country. These also include customary international law that have direct applicability within countries as well as international treaties that have been domesticated either through the process of incorporation or by virtue of direct applicability. In common law jurisdictions, the common law also represents a distinct legal order. With increasing globalization and the recognition by the international community that certain types of conduct call for international and/or extraterritorial regulation and sanction, some external legal orders operate directly, alongside state laws, within a country. An example is the creation of the Rome Statute of the International Criminal Court (ICC) which subjects individuals alleged to have committed war crimes and crimes against humanity to the jurisdiction of the ICC, regardless of where the crime was committed. ${ }^{29}$ Thus, in relation to conduct amounting to these types of crimes, a person is subject to the criminal law of the country where the crime is committed as well as to the Rome Statute. Another example can be seen in the existence of extraterritorial anti-bribery laws enacted by many western countries to prohibit their business corporations from engaging in corrupt activities in their overseas operations. Their business corporations operating in Nigeria, for instance, would be subject not only to Nigerian laws but also to their home countries' anti-bribery laws. ${ }^{30}$ Each of these normative legal orders usually represents a self-contained legal system that operates in parallel with the others. ${ }^{31}$ Tension arises where two or more of the legal orders operate

28 Helen Quane, 'Legal Pluralism and International Human Rights Law: Inherently Incompatible, Mutually Reinforcing or Something in Between?' (2013) 33(4) Oxford Journal of Legal Studies 676 (noting that examples of legal pluralism abound so much that there is hardly any jurisdiction in the world without 'some traces of legal pluralism'). 17 July 1998, 2187 UnTS 3, 37 ILM 999 (1998).

$30 \quad$ See, e.g., Foreign Corrupt Practices Act, 15 USC $§ 78 \mathrm{dd}$ (1977) (Us); Corruption of Foreign Public Officials Act, SC 1998, c 34 (Canada).

31 Quane has argued that ' $[w]$ hen viewed in conjunction with a state's national law, the very existence of international human rights law represents a particular form of legal pluralism.' Quane (n 28) 677 . 
with regard to a particular case or transaction and the application of one would be incompatible or inconsistent with the application of the other(s).

The advent of legal pluralism in Nigeria is historically connected with the advent of colonialism. Before the official birth of Nigeria, represented by the amalgamation of the Southern and Northern Protectorates in 1914 by the British colonial administrators, the various peoples had their autonomous legal systems that regulated their relations with one another. In southern Nigeria, which was predominantly Christian, the operative law was unwritten customary law, defined as "a body of rules and norms whose legitimacy is rooted in tradition and is claimed to have existed since time immemorial." 32 Such law is "organic in that it is not static, [and] is regulatory in that it controls the lives and transactions of the community subject to it." ${ }^{33}$ It is distinguishable from custom. While custom is a rule of practice, customary law is such practice that has attained obligatory or binding character within the community to whom it applies. ${ }^{34}$ It obtains its obligatory character from the assent of the community who evidence their assent by the creation of sanctions and enforcement mechanisms for its violation. ${ }^{35}$ Customary laws are generally unwritten and vary from place to place, ethnic group to ethnic group, village to village and sometimes even from one clan to another. Factors accounting for such extreme diversity include the historical and socio-economic experiences of the different peoples, which is why caution is required before making value judgments about customary laws. ${ }^{36}$ The existence of customary law, however, is a question of fact and must be proved in the same manner as facts are proved. ${ }^{37}$

On the other hand, in northern Nigeria, which was predominantly Muslim, the operative law was the Islamic law of the Maliki School..$^{38}$ In contrast to

32 Akua Kuenyehia, 'Women, Marriage, and Intestate Succession in the Context of Legal Pluralism in Africa' (2006) 40 University of California at Davis Law Review 390. Bilewu Oyewumiv Amos Owoade Oginesa, [1990] 3 NWL (Pt 196) 182 (CA, Nigeria) 207.

34 RN Nwabueze, 'The Dynamics and Genius of Nigeria's Indigenous Legal Order' (2002) 1 Indigenous Law Journal 158.

35 Ibid (noting that the existence of sanction is the distinguishing character between customary law and custom).

$36 \quad$ Kuenyehia (n 32$) 388$.

37 Nigerian Evidence Act, s 14(1); Oyewunmiv Ogunsesan (1990) NWLR (Pt 137) 182. Chilenye Nwapi, 'International Treaties in Nigerian and Canadian Courts' (2011) 19 African Journal of International \& Comparative Law 56 . The regarding of customary law as a question of fact has been criticized by the Supreme Court of Nigeria as 'an annoying vestige of colonialism'. See, e.g., Ugo v Obiekwe (1989) 1 NWLR (pt 99) 566, 583 .

38 JA Arewa, 'The Evolution of the Nigerian Legal Order: Implications for Effectiveness, Economic Growth and Sustainable Development' (2013) NIALS Journal of Law and Public Policy 42. 
customary law, Islamic law was written, based on Qur'anic injunctions, the practices of Prophet Mohammed and the consensus of Islamic scholars. ${ }^{39}$ Because of its written nature, what constitutes Islamic law is more settled than what constitutes customary law, and unlike customary law, Islamic law enjoys considerable uniformity across localities.

With the advent of colonial rule, statute law and the common law (the received English law) were born. The British Colonial Administration enacted ordinances that subjugated pre-existing customary laws and established Native Courts that abrogated, replaced or assumed pre-eminence over traditional adjudicatory institutions. As Yakubu puts it, while 'the place of customary law in the operation of laws in Nigeria was assured..., the Supreme Court Ordinance No 6 of 1914 allowed the operation of customary law only where the rule of customary law being sought to be enforced was not repugnant to natural justice, equity and good conscience nor compatible with the law for the time being in force. ${ }^{40}$ There is a third test: customary law must not be contrary to public policy. ${ }^{41}$ The 'law for the time being in force' is understood as the ordinances enacted by the Colonial Administration (i.e., statutes) as well as the common law. ${ }^{42}$ However, the subjugation of customary law to the above validity tests did not end with the end of colonial rule but was retained and still remains operational to this day. ${ }^{43}$ Thus, while the courts have jurisdiction to apply customary law, their application of customary law is subject to the validity tests.

The advent of military rule in Nigeria added yet another layer of legal order in the Nigerian legal system although strictly speaking the decrees enacted by the successive military governments did not constitute a distinct, self contained legal system, such as the customary legal system, but could be classed in the same category as statute law. However, the fact that, in addition to their revolutionary character, decrees did not derive their authority from the pre-existing legal order conferred on them the status of a separate legal order superior to the pre-existing legal order. In Lakanmi \& Anor $v$ Attorney General of the Western State \& Others, ${ }^{44}$ the Supreme Court of Nigeria declared that

39 Ibid.

40 JA Yakubu, 'Colonialism, Customary Law and Post-Colonial State in Africa: The Case of Nigeria' (Paper prepared for CODESRIA'S 1oth General Assembly on 'Africa in the New Millennium', Kampala, Uganda) 8-12 December 2002, $4<$ www.nigerianlawguru .com/articles/customary\%2olaw\%20and\%2oprocedure/COLONIALISM,CUSTOMARY \%20LAW\%20\&\%20POST\%20-\%20COLONIAL\%20STATE\%20-NIGERIA.pdf> accessed 12 October 2016.

41 Evidence Act, s 14(3).

42 Re Adedavoh (1951) 13 WACA 304.

43 Yakubu (n 40) 5 .

$44 \quad(1971) 1$ UILJ. 
"[a] new legislative power was created [with the promulgation of Decree No 1 of 1966] which does not derive its authority from any provision of the preexisting Constitution." 45 The Court stated that "once a Decree is made ... nothing, not even the provisions of the Constitution can derogate therefrom."46 Thus, military rule not only introduced a new legal order, it also altered the status of the constitution as the supreme law of the land in the hierarchy of norms in Nigeria. With the re-arrival of democratic rule in Nigeria in 1999, however, the promulgation of decrees not only ceased, the supremacy of preexisting decrees over the constitution also became a thing of the past. In fact, the 1999 Constitution abrogated the supremacy provisions of pre-existing decrees and saved the provisions that were not inconsistent with it, transforming them however to the status of ordinary legislation. ${ }^{47}$ This means that those decree provisions, in so far as they were not abrogated, were placed at par with ordinary legislation.

In the hierarchy of these legal orders, aside the constitution which acts as the supreme organic law of the land, statute law takes precedence over all the other laws. Though customary law is different from Islamic law, they share equal status. ${ }^{48}$ The status of customary law in relation to the common law is less clear. As noted, the repugnancy test mandates compatibility of customary law with any law for the time being in force, the latter being understood as including both statue law and the common law. However, in Adesubokan $v$ Yinusa, the Supreme Court of Nigeria condemned the application of the common law in a manner that would strip a person of any benefits conferred on them under customary law that has already passed the repugnancy test. ${ }^{49}$ This implies that where a rule of customary law has passed the repugnancy test, any conflict between it and a rule of common law would be resolved in favour of customary law.

45 Ibid. See то Elias, Africa and the Development of International Law (Richard Akinjide, Martinus Nijhof 1988) 114.

46 Ibid. See, also, Abacha v Fawehinmi (2001) AHRLR 172.

47 See Goniv Gambo (2002) FWLR (Pt 131) 1877.

48 ES Nwauche, 'The Constitutional Challenge of the Integration and Interaction of Customary and the Received English Common Law in Nigeria and Ghana' (2010) Tulane European \& Civil Law Forum 40.

49 (1971) NMLR 77. 


\section{$4 \quad$ Land Ownership and Control in Nigeria}

There are two systems of land ownership in Nigeria: ownership under customary law (or Islamic law) and statutory ownership which is governed by the Land Use Act, 1978 (LUA), ${ }^{50}$ although ownership rights acquired under customary law can be taken away by the State by virtue of LUA. In the pre-colonial era, the dominant characteristic in southern Nigeria was that land belonged to the community or groups within it, such as tribes, villages, clans or families, and not to individuals or the State. ${ }^{51}$ The head of the community or group in question held the land in trust for its members and administered the land on their behalf, a condition that highlighted the communal socio-political relationships wherein kinship and allegiance or homage to a local sovereign determined one's access to land. ${ }^{52}$ How land was allocated among and within households was based largely on marriage and customary rules of inheritance. ${ }^{53}$ Land was (and still is) regarded as embodying spiritual values of great significance. ${ }^{54}$ Therefore, communities were reluctant to permanently alienate land by sale to outsiders.

In northern Nigeria, all land was held by the imam in trust for the people and the cultivators enjoyed only the right of use. ${ }^{55}$ Interests in land under the operative Maliki School of Law could be transferred based on rules of succession. ${ }^{56}$ Land rights (over uncultivated land) could also be acquired from having the permission of the imam to cultivate land. ${ }^{57}$ Because initial acquisition of land was based predominantly on conquest, the Maliki law had

\footnotetext{
50 Cap L5, LFN 2004.

$5^{1} \quad$ KeijiroOtsuka\&FrankPlace, 'ChangesinLandTenureandAgricultural IntensificationinSubSaharan Africa' WIDER Working Paper, No 2014/051, $2<$ www.wider.unu.edu/publications/ working-papers/2014/en_GB/wp2014-051/> 15 October 2016.

52 AL Mabogunje, 'Land Reform in Nigeria: Progress, Problems and Prospects', World Bank Technical Committee for Land Reforms, 2007, 3 <http://siteresources.worldbank .org/EXTARD/Resources/336681-1236436879081/5893311-1271205116054/mabogunje.pdf> 15 October 2016.

53 Susana Lastarria-Cornhiel, 'Impact of Privatization on Gender and Property Rights in Africa' (1997) 25(8) World Development 1318.

54 Chilenye Nwapi, The Primacy of People in Development: Theoretical and Legal Perspectives on Public Participation in Oil and Gas Decision-Making (Lambert Academic Publishing 2012) 1. See, also, Odoemene (n 2) 260-261.

55 Steven Pierce, 'Pointing to Property: Colonialism and Knowledge about Land Tenure in Northern Nigeria' (2013) 83(1) Africa 145.

56 Ibid 144 .

57 Ibid.
} 
"confer[red] on the colonial conquerors rights to the land of the conquered."58 Vested with rights over lands, the colonial administration placed all land in the region under the control of the governor, with the effect that without the governor's consent, no one could acquire a valid right to the occupation and use of land. ${ }^{59}$

During the colonial period, the British Colonial Administration found the customary land tenure system in southern Nigeria hostile because it hindered easy access to land by the colonial government since access was dependent on the consent of customary land titleholders. These land titleholders were rarely individuals but a collection of people tied by one form of kinship or the other. Decision-making over land transfers were therefore collective rather than individual. And due to the spiritual values associated with land under customary laws, landowners were unwilling to part with their land even when significant compensations were offered. The Nigerian government was equally confronted by this same difficulty after independence. The government's response was to device a means of extending the system in northern Nigeria to the whole country, so as to make land easily available to the government for development purposes. ${ }^{60}$ The instrument for realizing this intention was LUA, a federal statute originally promulgated as Decree No 6 in 1978. According to Otubu, the act was borne out of the need 'to harmonize the land tenure system in the country,' address the problem of land speculation and ease the difficulty of the government obtaining land for development purposes. ${ }^{61}$ It was believed that the non-registration of land under customary law encouraged multiple land sales and that customary ownership was inimical to large-scale mechanized farming because it was difficult for farmers to obtain loan using family land as collateral. ${ }^{62}$ Although the act is not a constitutional enactment, it enjoys an extraordinary status in the body of Nigerian law following its subsequent annexation to the constitution. ${ }^{63}$ Its annexation to the constitution entails that it is superior to ordinary laws and its provisions cannot be

\footnotetext{
$5^{8} \quad$ Mabogunje (n $\left.5^{2}\right) 2$.

59 Ibid.

6o RT Ako, 'Nigeria's Land Use Act: An Anti-Thesis to Environmental Justice' (2009) 53(2) Journal of African Law 294.

61 Tunde Otubu, 'Land Reforms and the Future of Land Use Act in Nigeria' (2007) 4 Nigerian Current Law Review 130.

62 Јв Ejebowah, 'Land and Citizenship in Nigerian Ethnofederalism' in Karlo Basta, John McGarry and Richard Simeo (eds), Territorial Pluralism: Managing Difference in Multinational States (U BC Press 2015) 224.

63 See Constitution of the Federal Republic of Nigeria 1999, section 315(5).
} 
amended merely through the ordinary legislative process but only as though they were constitutional provisions. ${ }^{64}$ The act is thus regarded as a 'super act'. ${ }^{65}$

LUA grants ownership of all land in a state to the state governor, who holds and administers it 'in trust ... for the use and common benefit of all Nigerians. ${ }^{\prime 66}$ All land is thus managed and controlled by the governor of the relevant state; however, land in non-urban areas is managed and controlled by the relevant local government authority on behalf of the governor of that state. ${ }^{67}$ All land within the Federal Capital Territory (FCT) is vested under the Nigerian constitution in the government of the Federal Republic of Nigeria. ${ }^{68}$ There is thus no individual ownership of land. The best an individual can acquire is a right of use, described as a 'right of occupancy', which is granted by the governor of the state where the land is situated or, in the case of land in non-urban areas, by the local government authority in the name of the governor. Persons who owned land prior to the enactment of the Act had their title reduced to beneficial ownership with only an equitable interest in the lands a right to hold and occupy a piece of land for a term of years upon payment of specified rent and fulfillment of other covenants and conditions. ${ }^{69} \mathrm{~A}$ right of occupancy is thus a mere lease, and it cannot be transferred or otherwise alienated without the consent of the governor, ${ }^{70}$ who reserves the right to revoke it on grounds of 'overriding public interest', ${ }^{11}$ which includes the requirement of the land for public development projects. ${ }^{72}$ Large-scale agricultural projects whose main purpose is to promote agricultural development in the country would arguably pass the overriding public interest test. A person whose right is revoked is entitled to no more than compensation. ${ }^{73}$

There are two types of rights of occupancy recognized under the Act: a customary right of occupancy and a statutory right of occupancy. Whereas

64 Ibid, s. 315(5). See AmD Olong, Land Law in Nigeria (2nd edn Malthouse Press, Surulere (Lagos) 2011) 24 .

65 Chilenye Nwapi, 'Land Ownership, Mineral Development and Agriculture in Nigeria: An Examination of Key Issues and Challenges' in R Ako and Ds Olawuyi (eds), Food and Agricultural Law: Readings on Sustainable Agriculture and the Law in Nigeria (Afe Babalola University Press 2015) 32.

66 LUA (n 5o) s 1.

67 Ibid s 6.

681999 Constitution (n 66) s. 297(2). See, also, LUA (n 5o) s $51(2)$.

$69 \quad$ LUA (n 50) s 5(1). See Kachallav Banki (2006) All FWLR (Pt 309) 1420.

$70 \quad$ LUA (n 5o) ss 21 and 22.

71 Ibid s 28(1).

72 Ibid s $28(2)$ (c) and (3)(b).

73 Ibid s 29 . 
a customary right of occupancy is granted in respect of land in non-urban areas, ${ }^{74}$ a statutory right of occupancy is granted in respect of land in urban areas. ${ }^{75}$ The wording of the Act permits the governor to grant a statutory right of occupancy in respect of all land, whether urban or non-urban. In practice, however, lands in non-urban areas are administered by local government authorities. What local government authorities can grant in respect of such land, however, is only a customary right of occupancy. Whether an area is urban or non-urban is determined by the governor who can decide to designate all land within the state as urban areas, thereby precluding local government authorities from granting customary rights of occupancy.

From the above analyses, it can be seen that although LUA governs ownership and acquisition of land in Nigeria, customary law still has a place in the acquisition of land. This is contrary to early judicial decisions on LUA, which had held that the Act abolished customary land law. ${ }^{76}$ In Abioye $v$ Yakubu, ${ }^{77}$ however, where a customary tenant claimed that by virtue of LUA he was no longer the tenant of his customary landlord but that of the Local Government, the Supreme Court ruled that the customary law governing the relationship between the customary landlord and his tenant was still intact.

\section{Implications of the Plurality of Land Tenure Rights for Gender} Equality in Nigeria

Under customary law, access to land is based predominantly on inheritance. Inheritance itself is based on a predetermined system of succession which varies from locality to locality. Gender, marriage and one's status in the family or household play a significant role in the law of inheritance. The issue of inheritance is therefore critical because it is one way by which women can access or be denied access to land and other types of economic resources. ${ }^{78}$ 'Since gender plays a significant role in kinship systems and is a basic factor in sociocultural structures, values, and practices,' Lastarria-Cornhiel has argued, 'it is also a significant determinant of who has land rights in customary tenure systems. ${ }^{79}$

\footnotetext{
74 Ibid s 6(1).

75 Ibid s 5 .

76 See, e.g., Nkwocha v Governor of Anambra State (1984) 6 SC 362. See, also, LK Agbosu, 'The Land Use Act and the State of Nigerian Land Law' (1988) 32 Journal of African Law 13.

$77 \quad$ [2001] FWLR (pt 83) 2212.

78 Kuenyehia $\left(\mathrm{n}_{32}\right) 387$.

79 Lastarria-Cornhiel (n 53) 1318.
} 
Given that most Nigerian communities are agrarian and live on subsistence agriculture, a lack of access to land - the most important agricultural resource has significant implications for access to economic resources. In particular, it 'thwarts' the efforts of women to achieve 'economic independence for themselves and their families. ${ }^{\prime} 0$

The customary land tenure system is fraught with uncertainty, entrenches inequality and is not readily receptive to change. Its uncertainty stems from its largely unwritten character, which makes it difficult to ascertain not only its actual contents but even its existence. Reliance on oral testimony to prove ownership of land is fraught with problems. Besides the fact that time and old age could result in loss of memory while the death of certain persons may lead to complete loss of evidence, there is a high risk of parties not upholding their agreement. ${ }^{81}$ Lack of documentation can also promote land speculation and multiple sale of a single land. ${ }^{82}$ It also creates difficulties when the government needs to determine to whom compensation is due when land is expropriated, for only verified landowners will be compensated and verification is difficult in the absence of documentation.

However, the major problem with the customary land tenure system in Nigeria is its creation, not merely entrenchment, of inequality. Women in Nigeria (particularly rural women) constitute a major proportion of active farmers, from where they shoulder a greater responsibility to provide subsistence for their families. ${ }^{83}$ One would think then that women's greater participation in such a very important land-based activity as agriculture and their greater responsibility to provide food for their families would be matched in customary law by their being granted proportionately greater access to land. But, as is captured in several judicial authorities, women's access to land under customary law has been anything but equal to men's.

In Lewis $v$ Bankole ${ }^{84}$ - one of the notable early cases on inheritance in Nigeria - the issue was who had the right in Lagos State, southwestern Nigeria, to benefit from the property of the deceased who died intestate, leaving behind five sons and seven daughters. Upon the death of the deceased, his

\footnotetext{
8 o Kuenyehia $\left(\mathrm{n}_{32}\right){ }_{3} 87$.

$81 \quad$ Nwapi, 'Land Ownership' (n 65) 40.

82 Mabogunje (n $\left.5^{2}\right) 3$.

83 Adetoun Ilumoka, 'Globalization and the Re-Establishment of Women's Land Rights in Nigeria: The Role of Legal History' (2012) 87(2) Chicago-Kent Law Review 423; Food and Agricultural Organization, Women, Agriculture and Rural Development: A Synthesis Report of the African Region (FAO 1995).

$84 \quad$ [1908] 1 NLR 81.
} 
eldest son took over the headship of the family, despite having an older sister. Two issues arose before the court: (1) Who was the family head (in a situation where the eldest persons in the family were female)? (2) Who had the right to inherit family property? Based on evidence before it, the court ruled that the eldest surviving son of the deceased was the family head. In Lopez $v$ Lopez, ${ }^{85}$ the court stated, also with regard to Lagos State, that '[f]emales cannot inherit land, they can only have the right to stay in the house. A female has no right to bring her husband to live in the family house, but she does not lose her right to return to it by marriage. Her children have the right.' Thus, while men, married or unmarried, can inherit land, women, married or not, cannot. These cases are location-specific and so cannot theoretically be taken to represent the rule of customary law throughout Nigeria and may not even represent the rule throughout Lagos State, since customary law varies from place to place. ${ }^{86}$ But they are generally reflective of the rule in other parts of southern Nigeria.

Given the significant influence the family head can have on the control and disposal of family property, the mere denial of female children the right to become family heads has far-reaching effects. As will be seen in the next section of this article, however, the courts have revisited the question of the validity of several customary laws in Nigeria that denied women the right to inherit land. But it must be noted that while customary law restricts women's access to land, 'under optimal circumstances of land abundance and peace,' it does 'provide the means and access to land for women to maintain themselves and their children, usually through their husband's family, and sometimes their own birth family.'87 Such provisions come by way of giving women the right to cultivate family farmlands. Even though they cannot ordinarily inherit the land under customary law, the right to cultivate farmlands is always preserved for women.

If customary law makes women economically dependent, the facilitation of land grab through the instrumentality of state law frustrates the efforts of women to overcome the shortcomings of customary law and achieve economic independence. The root of this problem can be traced to the doctrine of eminent domain - the state's right to expropriate property for public use,

\footnotetext{
85 [1924] 5 NLR 50 at 53 .

86 Nwauche has observed the tendency of Nigerian courts to treat these rules as though they were the same throughout the country. Nwauche (n 44) 45 .

87 Lastarria-Cornhiel (n 56) 1324 (citing Fiona Mackenzie, “'A Farm is Like a Child Who Cannot be Left Unguarded": Gender, Land and Labour in Central Province, Kenya' (1995) IDs Bulletin, Vol 26, No 1).
} 
subject only to payment of compensation to the 'landowner'.8 9 The doctrine constitutes a significant threat to security of land tenure central to a landowner's decision to make agricultural investments.

One of the first blows LuA dealt on women was the almost complete breakdown of the general sense of obligation which families and communities owed towards individual family or community members, including and particularly women. This was achieved through the transfer of land ownership from the family to the State, the consequent 'transformation of land from a source of food to an asset'89 and the further consequence of commercialization of land which resulted in its scarcity and astronomical rises in land prices beyond the reach of previous customary owners. Odoemene writes that as a result of LUA most Nigerian cities have become 'land speculators' paradise', while in rural areas top government functionaries have exploited the act to dispossess 'illiterate natives of their lands. ${ }^{90}$ The Act also transformed the orientation of individual family members towards land: men, who have historically determined who gains access to land, began to see land as private property to be selfappropriated and the cultivation rights which women possessed were gradually eroded. Davison writes, albeit in relation to Kenya, that a widow may be forced by her husband's family out of the land she has held cultivation rights. ${ }^{91}$ The role of land grab in this regard is that it has worsened the plight of women by transferring ownership and control rights from the family and community to private, mostly 'foreign', investors who are further removed from rural women. The few cultivation rights still remaining for women, which depend on the existence of a male relative, are thereby effectively whitewashed.

Lawry et al have underscored the importance of security of tenure, which they regard as 'a pre-condition to farm investments that foster productivity and increase farm incomes. ${ }^{92}$ In their assessment of whether the effects, on agriculture and livelihood, of interventions to strengthen land rights are the same or different for men as for women, they find that 'social impacts resulting from tenure interventions can be significant, unpredictable and in some instances

88 Franklin Obeng-Odoom, 'Natural Resource Abundance and Eminent Domain: A Case Study from Africa' (2012) 27(4) Local Economy 321.

89 Lastarria-Cornhiel ( $\left.\mathrm{n}_{56}\right)^{1324}$.

9o Odoemene (n 7$) 262$.

91 Jean Davison, 'Who Owns What? Land Registration and Tensions in Gender Relations of Production in Kenya' in Jean Davison (ed), Agriculture, Women, and Land: The African Experience (Westview Press 1988).

92 Steven Lawry et al, 'The Impact of Land Property Rights Interventions on Investment and Agricultural Productivity in Developing Countries: A Systematic Review' (2014) 1 Campbell Systematic Review 10. 
have negative consequences such as displacement or diminished property rights for women. ${ }^{93}$ While there is no legal barrier to women purchasing land in their own names, the gender-neutrality of the land market has been rightly questioned: besides the persistence of ideological bias against women's acquisition of their own land, women generally lack the capital to purchase land, and where they are able to raise the capital, they are generally unable to obtain loans to invest in the land acquired because their previous denial of the right to own land renders them unable to provide collateral to obtain such loans. ${ }^{94}$ In some parts of Africa, such as Gambia, women are discriminated against by land administrators in the selection of applicants for land grants. ${ }^{95}$

6

\section{Legislative and Jurisprudential Bases for Challenging Land Grab- Related Gender Discrimination in Nigeria and the Inadequacy of Law to Fully Address Gender-Related Problems}

The early cases cited in the foregoing section demonstrate that it was not unusual for Nigerian women to challenge the patrimonial nature of the customary land tenure system and to demand their entitlement to family property. That challenge has continued to this day. What has not received judicial challenge, however, is the role of LUA in the marginalization of Nigerian women. Indeed, challenges to land grab based on LUA are unlikely to succeed. This is because the Act gives broad powers to the governor to dispossess individuals of their interests in land for overriding public interests ${ }^{96}$ which, as argued earlier, includes large-scale agricultural projects whose main purpose is to ensure food security in the country. The reason is further connected with the constitutional flavour of LUA, which renders the provisions of any other statute inconsistent therewith invalid. In fact, its constitutional flavour impedes attempts to enact inconsistent statutes since any proposed amendments to the Act must follow the rigours of constitutional amendments. This has prompted scholars, such as the present writer, to call for a delinking of the Act from the constitution to enable its amendments to follow the ordinary legislative amendment process:

\footnotetext{
$93 \quad$ Ibid 9.

94 Lastarria-Cornhiel ( $\left.\mathrm{n}_{5} 6\right)$ 1326-1327.

95 Ms Freudenberger, 'Tenure and Natural Resources in The Gambia: Summary of Research Findings and Policy Options', Land Tenure Centre Working Paper No 40, University of Wisconsin, Madison, August 2000, 29-30 <http://ageconsearch.umn.edu/bitstream/ 12788/1/ltcwp40.pdf >. 20 October 2016.

$96 \quad$ LUA (n 53) s 28(2)(c) and (3)(b).
} 
It may be necessary to consider decentralizing land use policy and regulation to grant states the power to enact their own laws to regulate land within their territory instead of having one central law regulating all lands in the country.... This will encourage states to formulate land use policies that are in tune with local realities and aspirations. ${ }^{97}$

Land is too close to the everyday life of ordinary people in rural areas for central regulation.

One potentially sustainable legislative challenge may be based on the impact of such land acquisitions on local populations, such as impacts associated with dispossession, which can be addressed through the Environmental Impact Assessment (EIA) Act. ${ }^{98}$ The EIA Act provides that when a land development scheme or an agricultural project covers 500 hectares of land or more involving change in type of agricultural use or when an agricultural program involves the resettlement of 100 households or more, before commencing the activity an EIA evaluating the project's potential social and environmental impacts shall be carried out. ${ }^{99}$ The same applies when forest land is to be converted to other land use where such land is 'within the catchment area of reservoirs used for municipal water supply, irrigation or hydro power generation or in areas adjacent to state and national parks and national marine parks', or where mangrove swamps covering an area of 50 hectares or more are to be converted to 'industrial, housing or agricultural use.'100 However, EIA-based challenges are unlikely to result in non-acquisition of lands by agro-investors since the purpose of an EIA is to evaluate the impact on the public with a view to identifying and implementing mitigation measures. It is only where the potential impacts are considered extremely severe and effective mitigation measures are not available and a balance of economic and socio-environmental factors militate against the carrying out of a project that a project can be stopped. ${ }^{101}$

Gender-based challenges are possible only through the use of human rights instruments, in particular, section 42(1) of the 1999 Constitution, which protects the right to freedom from discrimination, and section 43, which

97 Nwapi, 'Land Ownership' (n 68) 42; Mabogunje (n 55).

98 Decree No 86 of 1992, 10 December 1992.

99 Ibid Schedule, para 1.

$100 \quad$ Ibid para 6.

101 For a detailed and useful discussion of the EIA process in Nigeria, albeit in a different context, see Allan Ingelson and Chilenye Nwapi, 'The Environmental Impact Assessment Process for Oil, Gas and Mining Projects in Nigeria: A Critical Analysis' (2014) 10(1) Law, Environment \& Development Journal 1-22. 
guarantees the right of every Nigerian, regardless of gender, to acquire and own immovable property anywhere in Nigeria. Instances where the courts have relied on the constitution to strike down gender-discriminatory customary laws abound. In Nzekwuv Nzekwu, ${ }^{102}$ the Supreme Court held that 'the plaintiff had the right of possession of her late husband's property and no member of her husband's family has the right to dispose of it or otherwise whilst one is still alive.' In Mojekwu v Mojekwu, ${ }^{103}$ the Court of Appeal struck down an Nnewi custom of 'oli-ekpe' which precluded daughters from inheriting their deceased fathers' property. In Mojekwu v Iwachukwu, ${ }^{104}$ although the Supreme Court rebuked the Court of Appeal for applying the repugnancy test to the oli-ekpe custom, it nevertheless upheld the Court of Appeal's holding in Mojekwu v Mojekwu affirming a woman's right to inherit property.

In 2014 the Supreme Court delivered two landmark decisions. In Anekwe $v$ Anekwe, ${ }^{105}$ the respondent's deceased husband was the half-brother of the appellant's father. The respondent sought a declaration that she was entitled to a statutory right of occupancy of a parcel of land belonging to her deceased husband, or, to a share in the proceeds of the sale of the land. Affirming the decisions of the lower courts upholding the woman's right to inherit her deceased husband's property, the Supreme Court stated in very strong terms that "[a]ny culture that disinherits a daughter from her father's estate or wife from her husband's property by reason of a God-instituted gender differential should be punitively and decisively dealt with."106 In Ukeje v Ukeje, ${ }^{107}$ a woman born out of wedlock sought a declaration against her step-mother and halfbrother that she was entitled to share in the estate of her deceased father. The Supreme Court rejected the respondents' contention that the woman's claim was contrary to Igbo customary law and stated that 'the Igbo native law and custom which deprives children born out of wedlock from sharing in the benefits of their father's estate is void because it conflicts with section 42(2) of the Constitution.' ${ }^{108}$ While these cases have paved the way for the end of the age-long anti-development discrimination against women in Nigeria, given the high illiteracy level in Nigerian rural areas, particularly in legal matters, it will take time before the discriminatory practices can stop and the impact of these judgments felt.

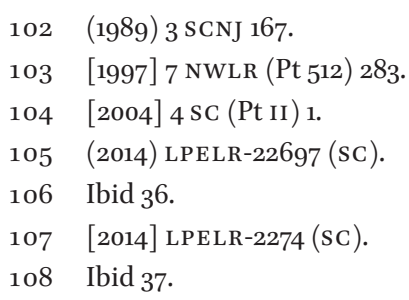


However, discrimination must be clearly established. In the cases considered above discrimination was obvious. In relation to LUA, it would be very difficult to establish discrimination. So long as there is a statutorily valid basis for dispossession, such as through LUA, the fact that women are more negatively impacted than men can hardly ground a discrimination lawsuit. It is therefore very difficult for women to obtain redress for dispossession occasioned by the application of LUA to facilitate land grab. It could therefore be rightly said that gender discriminations perpetrated through customary laws are easy to redress through the judicial process whereas those committed through the instrumentality of LUA are virtually impossible to redress. With the annexation of LUA to the constitution, challenges based on the fundamental rights provisions of the constitution are virtually out of the question since such annexation amounts to an adoption of the Act's provisions by the constitution. The only option left to women to challenge gender-related impacts of land grab is through the political process.

The political interventions envisaged here entail affirmative policies and actions by the political organs of government targeted specifically at providing economic empowerment and social protection to women. Examples include financial schemes designed specifically to provide low-interest loans to rural women engaged in agriculture, land policy schemes that allow agricultural women to obtain preferential treatment in the allocation of agricultural lands, and programs that provide training to women interested in seeking alternative means of livelihood. Governments at all levels are in a position to initiate any of these policies.

\section{$7 \quad$ Conclusion}

This article has examined the implications of legal pluralism on the promotion of gender inequality in the context of land grab in Nigeria. It finds that, like most other African countries, land grab is occurring in Nigeria. The incidence of land grab is driven by the quest by the Nigerian government to promote food security in the country. However, owing to the vulnerable status of women under the various customary laws in Nigeria, the negative implications of land grab are suffered most severely by women who dominate rural agriculture. Customary law is not in a position to protect their rights against the effects of land grab. But rather than statute law righting the wrongs of customary law, statute law, specifically LUA, denies women the few rights protected under customary law. While Nigerian courts have advanced the cause of Nigerian women through their nullification of various rules of customary law denying women rights to inherit land, the problems suffered by women occasioned 
by LUA's facilitation of land grab are difficult to redress. This is because those problems, in particular the dispossession of women's customary rights to cultivate land, cannot easily be brought under the rubric of discrimination since the consequences on women are unintended. The only effective option left to women to challenge the impacts of land grab on their livelihood is through the political process. 